\title{
IMPLEMENTASI FRAMEWORK LARAVEL PADA RANCANG BANGUN WEBSITE IAKN PALANGKA RAYA DENGAN METODE PROTOTYPE
}

\author{
Agri Apriliando \\ Institut Agama Kristen Negeri Palangka Raya. Jalan Tampung Penyang, RTA Milono Km. 6, Palangka Raya \\ agriapriliano@iaknpky.ac.id
}

\begin{abstract}
ABSTRAK
Pelayanan informasi yang dilakukan oleh Institut Agama Kristen Negeri Palangka Raya melalui media cetak, spanduk dan media sosial dirasa kurang optimal. Hal ini karena belum tersedianya media digital berupa website yang memuat informasi IAKN Palangka Raya untuk diakses kapan saja dan dimana saja melalui internet. Tulisan ini membahas implementasi framework laravel dan framework bootstrap pada website IAKN Palangka Raya. Tujuannya adalah untuk membuat website institusi sebagai media pengelolaan dan penyampaian informasi terkait IAKN Palangka Raya kepada masyarakat secara mudah, tepat dan cepat sesuai dengan perkembangan teknologi. Pada penelitian ini digunakan metode pengembangan perangkat lunak prototype. Metode prototype memiliki tahapan yang ringkas sehingga pengembangan sistem menjadi relatif cepat. Penelitian dilakukan melalui 3(tiga) tahapan yaitu studi pendahuluan, perancangan implementasi mock-up, dan ujicoba sistem. Berdasarkan penelitian ini dihasilkan Website IAKN Palangka Raya berbasis framework Laravel 8 dan framework 5. Website telah menerapkan antar muka mobile responsive sehingga susunan tampilan menjadi dinamis menyesuaikan dengan ukuran layar perangkat dari pengguna website. Fitur pencarian pada website ini menerapkan model full-text search sehingga meningkatkan performa proses pencarian informasi. Dengan menggunakan website, seluruh informasi mengenai IAKN Palangka Raya dapat dikelola dan disajikan secara dinamis dan aktual sesuai kebutuhan instansi dan masyarakat.
\end{abstract}

Kata kunci: framework laravel, bootstrap, rancang bangun website, prototype.

\begin{abstract}
Information services carried out by the State Christian Institute Palangka Raya (IAKN Palangka Raya) through printed media, printed banners and social media are still not optimal. This is due to the unavailability of digital media websites that contain IAKN Palangka Raya information to be accessed anytime and anywhere via the internet. This paper discusses the implementation of the laravel framework and the bootstrap framework on the IAKN Palangka Raya website. The purpose is to create an institutional website as a medium for managing and delivering information regarding the IAKN Palangka Raya to the public easily, precisely and quickly in accordance with technological developments. In this research, the prototype software development method was used. The prototype method has brief stages so that system development is relatively fast. The research was conducted in 3 (three) stages, namely a preliminary study, designing a mock-up implementation, and system testing. Based on this research, produced the IAKN Palangka Raya website based on the Laravel 8 framework dan framework 5. This website has also implemented a mobile responsive interface so that the display arrangement becomes dynamic according to the device screen size of the website user. The search feature on this website has implemented a full-text search model so as to improve the performance of the information search process. By using the website, all information regarding IAKN Palangka Raya can be managed and presented dynamically and in real time according to the needs of public.
\end{abstract}

Keywords: framework laravel, bootstrap, website design, prototype.

\section{Pendahuluan}

Perkembangan teknologi informasi era 4.0 masa kini telah merubah paradigma masyarakat terkait dengan informasi itu sendiri. Informasi tidak lagi hanya berupa tulisan dan gambar pada media cetak seperti koran, buku, atau selebaran, namun juga informasi dimaksud dapat diperoleh dimana dan kapan pun hanya dengan menggunakan perangkat teknologi internet. Perangkat teknologi tersebut dapat berupa televisi, komputer, laptop, smartphone, ataupun smartwatch. Hal ini dipandang sebagai peluang bagi Institut Agama Kristen Negeri Palangka Raya dalam melakukan sosialisasi ataupun penyampaian informasi secara efektif dan efisien kepada masyarakat atau pun kepada civitas akademika di lingkungan institusi. Dengan penerapan teknologi informasi, masyarakat akan dengan mudah mendapatkan informasi yang berkaitan dengan IAKN Palangka Raya.

Institut Agama Kristen Negeri Palangka Raya atau dikenal juga IAKN Palangka Raya adalah Perguruan Tinggi Kristen Negeri dibawah naungan Direktorat Bimbingan 
Masyarakat Kristen Kementerian Agama RI. IAKN Palangka Raya dahulu dikenal dengan STAKN Palangka Raya atau Sekolah Tinggi Agama Kristen Negeri telah berubah status menjadi Institut pada tahun 2020 lalu. Hal ini tertuang dalam Peraturan Presiden Nomor 23 Tahun 2020 tentang Institut Agama Kristen Negeri Palangka Raya. Perubahan status tersebut berdampak secara langsung terhadap seluruh informasi terkait IAKN Palangka Raya. Informasi dimaksud seperti Perubahan Nama Perguruan Tinggi, Organisasi dan Tata Kerja Perguruan Tinggi, pembukaan Fakultas, Jurusan dan Program Studi terbaru, Penerimaan Mahasiswa Baru, Lembaga, Unit Pelaksana Teknis dan informasi -informasi lainnya. Informasi tersebut harus disampaikan dengan efektif dan efisien dalam upaya sosialisasi kepada masyarakat khususnya siswa - siswa sekolah menengah di Palangka Raya atau pun Nasional. Hal ini dilakukan dalam rangka menjaring calon mahasiswa sebagai pengguna layanan pendidikan pada IAKN Palangka Raya selaku Lembaga Pendidikan Tinggi.

Pada upaya penerapan teknologi di IAKN Palangka Raya, diperlukan media digital seperti media sosial ataupun website. Dengan adanya website, informasi akan tersaji dan dengan mudah diakses menggunakan perangkat teknologi berbasis internet. Keberadaan website dipandang sebagai media yang diakui secara legal serta menyajikan informasi yang kredibel.

Penyampaian informasi yang saat ini dilakukan oleh IAKN Palangka Raya adalah dengan membuat spanduk, brosur dan dokumen lainnya untuk dicetak dan disebarluaskan kepada masyarakat. Hal ini tentu menimbulkan masalah karena memerlukan biaya dan waktu yang sangat besar dalam pelaksanaannya karena masih menggunakan cara tradisional dibanding dengan penggunaan teknologi informasi seperti mesin pencari google di internet yang dapat dilakukan dengan mudah, tepat dan cepat. Selain itu, IAKN Palangka Raya selaku lembaga pendidikan dituntut untuk beradaptasi sesuai dengan perkembangan zaman khususnya dalam penerapan dan penggunaan teknologi informasi.

Untuk mengatasi permasalahan di atas maka dilakukan pembuatan website bagi IAKN Palangka Raya. Adanya website dipandang sebagai media yang tepat untuk menyampaikan informasi - informasi secara mudah, tepat dan cepat kepada masyarakat. Pembuatan website IAKN Palangka Raya dilakukan dengan menggunakan Visual Studio Code (Text Editor), Bahasa Pemrograman PHP (Hypertext Preprocessor), Database MySQL, dan XAMPP (Web Server).

Website merupakan media informasi digital yang dapat digunakan untuk menyajikan informasi untuk disampaikan secara mudah dan cepat. Media tersebut dibangun menggunakan sintaks atau script yang dikenal dengan HTML (HyperText Markup Language) dan CSS (Cascading
Style Sheets). Penggunaan sintaks dimaksud untuk mengatur bagaimana sebuah informasi bisa tersaji dengan baik dan mudah untuk dimengerti. Data-data yang telah diolah sedemikian rupa menjadi informasi kemudian dibungkus ke dalam sintaks HTML dan CSS untuk ditampilkan ke dalam peramban pengguna internet. Website dapat juga merupakan kumpulan halaman yang memuat informasi berupa teks, gambar, suara, ataupun video membentuk rangkaian saling terkait di dalam jaringan-jaringan halaman. (Aziz dkk, 2020:5 I5-520)

Website umumnya digunakan sebagai sarana dalam menyampaikan informasi-informasi terkait kelembagaan atau pemerintahan termasuk di dalamnya memuat atau tidak terbatas pada informasi struktur organisasi, sejarah dan berita. Oleh karena itu, website menjadi penting dimiliki oleh suatu lembaga atau pemerintahan karena aksebilitasnya yang tinggi. (Ariawan dkk, 2020:16I-166)

\section{METODE}

Metode penelitian bertujuan untuk memberi pedoman pelaksanaan penelitian termasuk tahapan, waktu dan tempat. Penelitian ini dilakukan dengan menggunakan metode pengembangan perangkat lunak prototype. Metode prototype memiliki keunggulan karena menggunakan pendekatan dalam membangun sebuah sistem secara bertahap dan cepat. Dengan melakukan metode tersebut, maka tahapan menjadi lebih ringkas dan cepat untuk selanjutnya menuju tahapan evaluasi untuk mendapatkan hasil berupa mock-up aplikasi. Metode prototype dilakukan dalam beberapa tahapan yaitu pengumpulan data, perancangan, implementasi, evaluasi, dan perbaikan. (Megawaty, 2020:98-I0I)

Framework adalah kerangka kerja berupa komponenkomponen program yang memiliki fungsi tertentu untuk melaksanakan perintah sehingga penulisan kode pada program menjadi lebih efektif dan efisien. Namun demikian, penggunaan framework mengharuskan programmer untuk memahami aturan-aturan yang ditetapkan oleh framework tersebut. Laravel merupakan open-source framework dengan bahasa pemrograman PHP. Framework ditujukan untuk melakukan pengembangan website dengan pendekatan MVC (Model, View, Controller). MVC adalah metode pendekatan pengembangan perangkat lunak yang memisahkan logika pemrograman, database dan kode antar muka. MVC pada laravel dilakukan melalui proses routing yang menghubungkan user dengan controller, untuk selanjutnya menuju model dan resource view. (Sari dkk., 2020:32-36)

Framework adalah open-source framework dibuat oleh Mark Otto dan Jacob Thornton, yang saat itu bekerja di Twitter. framework diciptakan sebagai standar frontend toolsets bagi pengembang aplikasi web di berbagai perusahaan. Mengutip artikel pada blognya, Mark Otto memperkenalkan framework dikarenakan adanya 
Agri Apriliando, S.T. Implementasi Framework Laravel dan Bootstrap pada Rancang Bangun

Website IAKN Palangka Raya dengan Metode Prototype

ketidaksesuaian pada front-end requirements antar programmer sehingga terjadi kesulitan disisi pengembangan dan pemeliharaan yang berkelanjutan. Framework menjadi jawaban untuk permasalahan tersebut dengan menerapkan responsive design terhadap komponen-komponennya termasuk CSS dan Javascript ke dalam projek yang dikerjakan oleh programmer. Hal ini memungkinkan pengembang/ desainer/ programmer menuliskan kode secara ringkas untuk menjalankan beberapa fungsi sekaligus seperti mobile responsive, grid feature, javascript plugins, forms, buttons dan icon package. (Spurlock, 2013:I)

Berdasarkan metode pengembangan perangkat lunak prototype, maka penelitian ini dilakukan dengan dengan tahapan sebagai berikut.

I. Melakukan studi pendahuluan melalui wawancara, observasi dan studi pustaka terkait topik penelitian;

2. Melakukan perancangan dan implementasi mock-up;

3. Melakukan uji coba dan evaluasi.

Metode pengembangan prototype mengutamakan gambaran terhadap ide dan eksperimen suatu rancangan yang merupakan presentasi awal bagaimana sebuah sistem dapat berjalan. Pada tahapannya, metode ini melibatkan pengguna dalam melakukan perancangan atau pun uji coba terhadap bentuk representasi dari sistem berbentuk rancangan mock-up. Bentuk tersebut nantinya menjadi bahan rujukan evaluasi oleh pengguna dan pengembang website. (Yoko dkk., 2019:2।2-223)

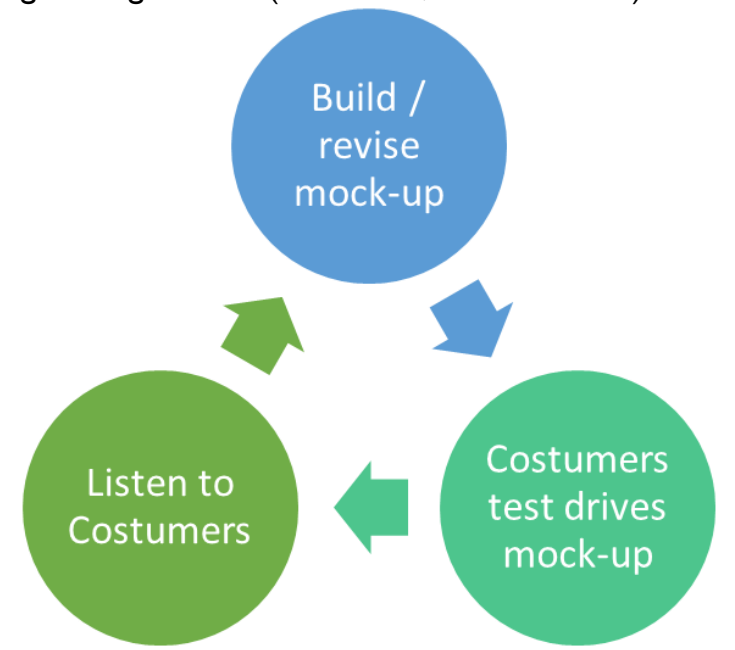

Gambar I. Model prototype (Yoko dkk., 2019:2।4)

Wawancara dilakukan kepada pengguna selaku web admin / pengelola website institusi. Observasi dengan melakukan pengamatan terhadap objek penelitian yaitu Institut Agama Kristen Negeri Palangka Raya di Jalan Tampung Penyang, RTA Milono Km. 6, Kecamatan Jekan Raya, Kota Palangka Raya. Studi pustaka dilakuan dengan mencari bahan referensi yang sesuai dengan kebutuhan dan topik penelitian.
Tahapan selanjutnya adalah penggunaan Use Case Diagram untuk mempresentasikan mengenai pengguna sistem, alur dan fungsi sistem, serta mendeskripsikan interaksi yang terjadi saat penggunaan sistem aplikasi. Use Case Diagram harus berdasarkan data-data yang telah diperoleh pada tahapan studi pendahuluan sehingga representasi sistem yang dihasilkan akan saling terkait dengan tahapan penulisan kode program.

Implementasi antar muka dan mock-up dilakukan sesuai framework Laravel 8 dan framework 5. Tahapan tersebut dilakukan berdasarkan komponen - komponen yang ada pada Use Case Diagram dengan penyesuaian terhadap data - data yang telah dikumpulkan. Implementasi antar muka menggunakan HTML (HyperText Markup Language) dan CSS (Cascading Style Sheets) yang dipadukan dengan framework framework 5. Framework 5 adalah versi terbaru dari framework Laravel yang memiliki kompabilitas tinggi terhadap teknologi peramban masa kini. Penggunaan framework Laravel 5 akan memberi ruang bagi programmer untuk melakukan perancangan desain dan penulisan sintaks secara ringkas dan cepat.

Pada tahap selanjutnya, peneliti melakukan integrasi perancangan antar muka framework 5 ke dalam framework Laravel 8 untuk menghasilkan mock-up aplikasi. Pada tahapan ini dilakukan penulisan kode program bahasa pemrograman PHP dengan menyesuaikan aturan pada dokumentasi Laravel 8.

Penerapan framework Laravel 8 pada pembuatan mock-up aplikasi bertujuan untuk menghasilkan representasi sistem yang akan berjalan serta memberi kemudahan bagi pengembang/ programmer untuk melakukan tahapan implementasi lanjutan termasuk penggunaan database dan proses deployment baik itu ke layanan cloud computing, server atau pun layanan hosting.

Mock-up aplikasi website selanjutnya dievaluasi oleh pengguna untuk melihat kesesuaian antara rancangan dan hasil. Evaluasi dimaksud adalah tahapan costumer test drives mock-up yaitu pengujian terhadap mock-up aplikasi termasuk antar muka, informasi dan interaksi pengguna dengan aplikasi web atau pun sebaliknya.

\section{HASIL DAN PEMBAHASAN}

Berdasarkan studi pendahuluan, diketahui bahwa IAKN Palangka Raya belum memiliki website institusi. Bentuk layanan informasi di tingkat institusi dilakukan dengan sosialisasi tatap muka, melalui spanduk, media cetak, dan penggunaan media sosial seperti facebook dan instagram. Informasi yang dilayani terkait dengan perubahan status perguruan tinggi, struktur organisasi, pembukaan fakultas dan program studi baru serta informasi kegiatan kampus. Berdasarkan data yang telah diperoleh pada studi pendahuluan selanjutnya dilakukan analisis data. Analisis data perlu dilakukan untuk menghasilkan informasi 
kebutuhan pengguna, serta kebutuhan data dan sistem. Kebutuhan pengguna terbagi menjadi dua jenis kegiatan, yaitu :

I. Pengguna admin

Admin memiliki hak untuk mengelola pengguna editor/author/penulis konten, mengelola konten info, mengelola konten berita;

2. Pengguna editor/author/penulis konten

Pengguna ini memiliki hak untuk mengelola konten info dan mengelola konten berita.

Adapun analisis terhadap kebutuhan data berupa sekumpulan data-data yang diperlukan pada perancangan sistem, termasuk seleksi dan normalisasi data. Berikut ini implementasi database yang berisi daftar tabel data yang diperlukan termasuk di dalamnya struktur dan relasi antar tabel data.

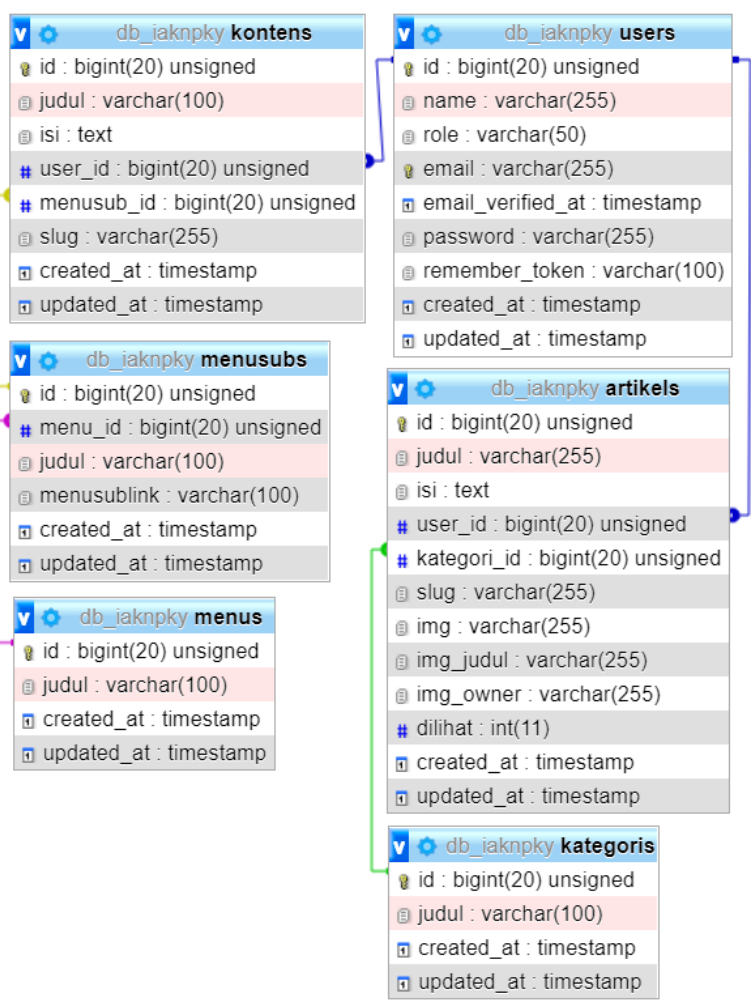

Gambar I. Struktur dan Relasi Tabel Data I

Data-data tersebut disimpan ke dalam database, untuk kemudian dikemas dan disajikan sebagai informasi pada halaman website.

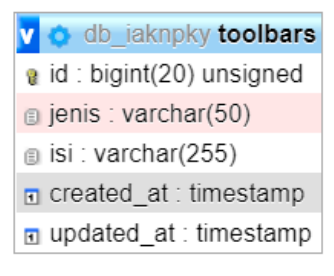

\begin{tabular}{|c|}
\hline $\mathbf{v} \quad \mathrm{db}$ iaknpky sessions \\
\hline id : varchar(255) \\
\hline \# user_id : bigint(20) unsigned \\
\hline (1) ip_address : varchar(45) \\
\hline B user_agent : text \\
\hline 自 payload: text \\
\hline \# last_activity : int(11) \\
\hline
\end{tabular}

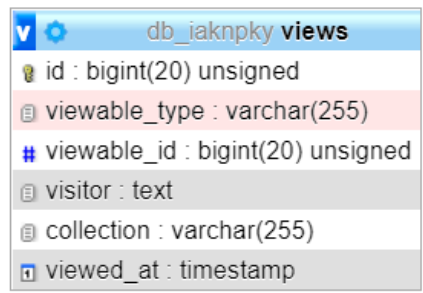

\begin{tabular}{|c|}
\hline $\mathbf{v}$ o db_iaknpky pageviews \\
\hline ४ id : bigint(20) unsigned \\
\hline (1) page : varchar(255) \\
\hline (1) ip_add : varchar(255) \\
\hline (1) tgl : varchar(255) \\
\hline (1) created_at : timestamp \\
\hline (1) updated_at : timestamp \\
\hline
\end{tabular}

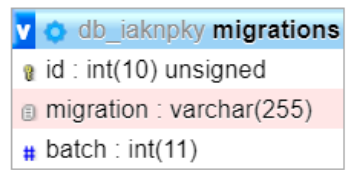

Gambar 2. Struktur dan Relasi Tabel Data II Struktur database bertujuan untuk menggambarkan hubungan antar data, agar tidak terjadi pengulangan data yang membuat database menjadi tidak efisien. Struktur dan relasi tabel data tersebut akan membantu programmer dalam melakukan implementasi database, karena jenis dan kriteria data telah diperoleh dan disusun secara sistematis.

Berikut ini adalah Use Case Diagram untuk menggambarkan pengguna, fungsi dan proses yang terjadi pada website.

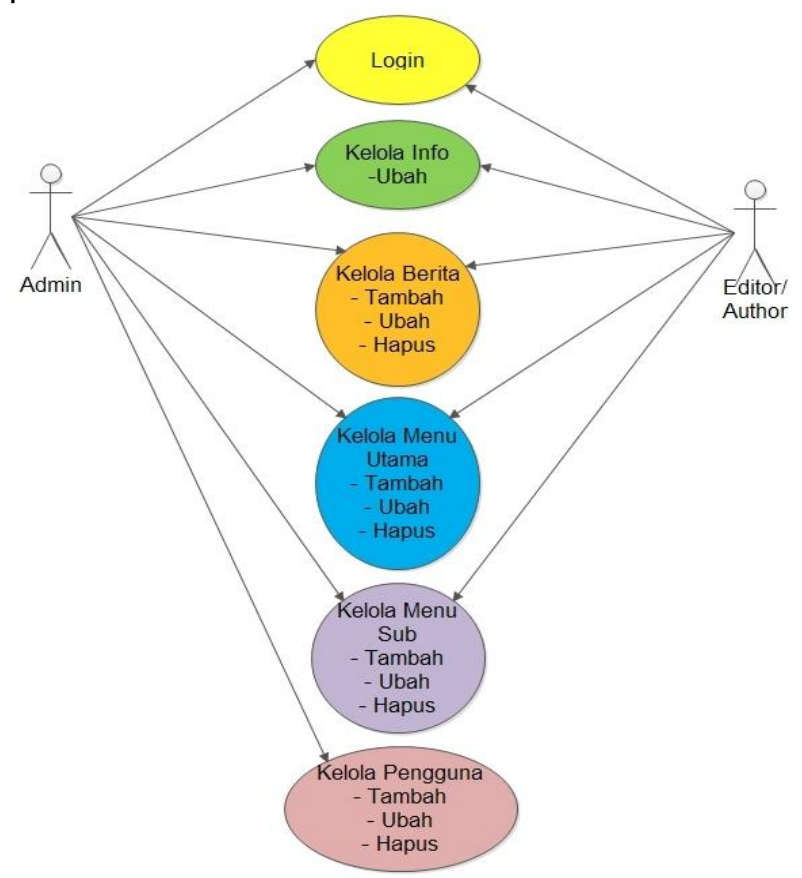

Gambar 3. Use Case Diagram 
Berdasarkan Use Case Diagram diketahui pengelola website terdiri dari 2 jenis dengan hak akses fitur yang berbeda-beda. Pengelola admin memiliki akses untuk login, kelola info, kelola berita, kelola menu, kelola menu sub, dan kelola pengguna. Adapun pengelola editor memiliki hak untuk login, kelola info, kelola berita, kelola menu dan kelola menu sub. Adapun hasil analisis terhadap kebutuhan sistem menghasilkan kebutuhan minimum spesifikasi perangkat keras dan perangkat lunak yang tampak pada tabel berikut ini.

Tabel I. Kebutuhan Perangkat Keras

\begin{tabular}{|l|l|l|}
\hline No & $\begin{array}{l}\text { Perangkat } \\
\text { Keras }\end{array}$ & Spesifikasi \\
\hline I & Prosesor & I.8 GHz atau lebih \\
\hline 2 & Hardisk & I50 GB atau lebih \\
\hline 3 & RAM & I,5 GB atau lebih \\
\hline 4 & Monitor & Resolusi I 366 $\times 768$ \\
\hline 5 & Keyboard & Standart QWERTY \\
\hline 6 & Wifi / LAN & Terkoneksi Internet \\
\hline
\end{tabular}

Tabel 2. Kebutuhan Perangkat Lunak

\begin{tabular}{|l|l|l|}
\hline No & $\begin{array}{l}\text { Perangkat } \\
\text { Lunak }\end{array}$ & Spesifikasi \\
\hline I & Sistem Operasi & Windows 7 \\
\hline 2 & Peramban & $\begin{array}{l}\text { Chrome atau Mozilla } \\
\text { Firefox terbaru }\end{array}$ \\
\hline 3 & Text Editor & $\begin{array}{l}\text { Visual Studio Code } \\
\text { terbaru }\end{array}$ \\
\hline 4 & XAMPP & Versi 7.4.I I \\
\hline 5 & PHP Framework & Laravel 8 \\
\hline 6 & CSS Framework & Bootstrap 5 \\
\hline 7 & Database & MySQL \\
\hline
\end{tabular}

Berdasarkan hasil analisis tersebut selanjutnya peneliti melakukan implementasi Bootstrap 5 pada perancangan antar muka pengunjung aplikasi website. Tampilan antar muka pengunjung website terbagi menjadi 4 jenis yaitu halaman beranda, halaman info, halaman daftar berita dan halaman berita. Antar muka halaman beranda terdiri dari 7 kolom yaitu :

I. Navigasi

Kolom ini memuat link menuju halaman konten info

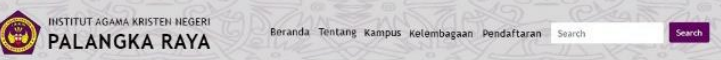

Gambar 4. Desain menu navigasi

2. Carousel Slide Banner
Kolom ini memuat banner atau info gambar berbentuk slide yang akan ditayangkan secara bergantian sejumlah 4 slide.

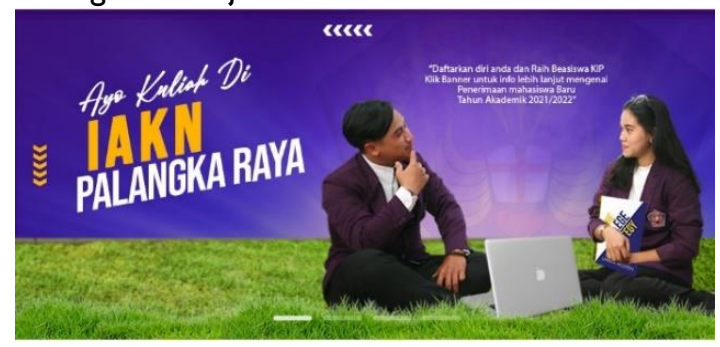

Gambar 5. Desain Carousel Slide Banner

3. Berita

Menampilkan ringkasan 3 (tiga) berita terbaru berdasarkan tanggal rilisnya berita.

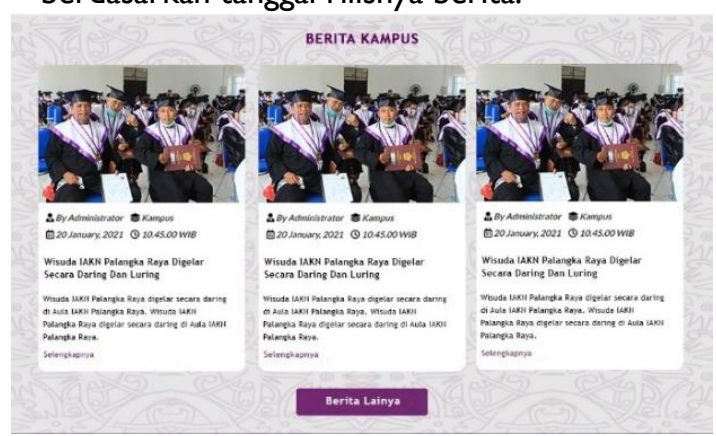

Gambar 6. Desain Berita Beranda

4. IAKN Palangka Raya dalam angka

Memuat ringkasan statistik kampus secara ringkas dalam bentuk gambar yang dapat diklik (link shortcut) untuk menampilkan informasi selengkapnya.

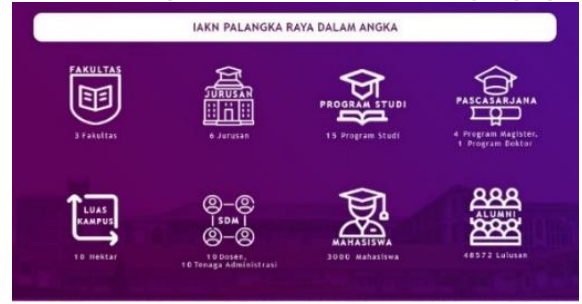

Gambar 7. Desain Kolom dalam Angka

5. Layanan

Menampilkan link menuju aplikasi tertentu

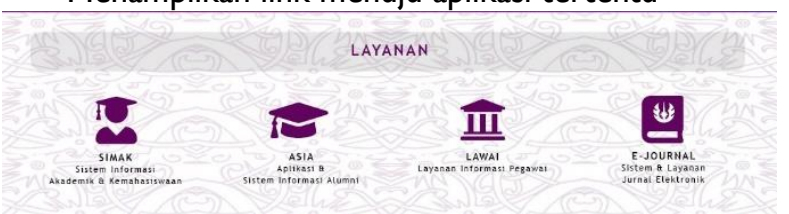

Gambar 8. Desain kolom Layanan

6. Kerja Sama

Daftar direct url menuju website instansi/lembaga pemerintah terkait.

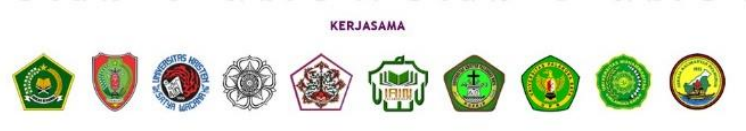

Gambar 9. Desain Kolom Kerja Sama 
7. Footer

Berisi informasi email, alamat, telepon, quick link, link media sosial, jumlah pengunjung.

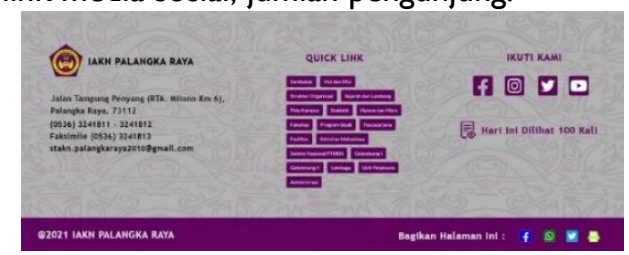

Gambar 10. Desain Kolom Footer

Antar muka halaman info terdiri dari 3(tiga) kolom yaitu

I. Navigasi

2. Konten Info

Kolom ini berisi judul dan isi konten info termasuk teks, gambar, audio, dan video

3. Footer

Antar muka halaman daftar berita terdiri dari 5(lima) kolom yaitu :

I. Navigasi

2. Daftar Berita

Berisi daftar yang memuat 4(empat) berita terbaru untuk setiap halaman.

3. Berita Terpopuler

4. Berita Terbaru

5. Footer

Antar muka halaman berita terdiri dari 7 kolom yaitu :

I. Navigasi

2. Judul

Memuat judul berita, termasuk juga jumlah viewer, kategori berita, author, dan waktu rilis.

3. Gambar / Foto

Memuat gambar/foto berita, keterangan, dan info pemilik.

4. Isi Berita

Memuat uraian berita secara lengkap termasuk foto dan paragraph berita.

5. Berita Terpopuler

6. Berita Terbaru

7. Footer

Selanjutnya dilakukan integrasi desain Bootstrap 5 ke dalam framework Laravel 8. Pada tahapan ini juga dilakukan implementasi fungsi-fungsi ke dalam bahasa pemrograman untuk melakukan proses yang telah dirancang. Implementasi tersebut dilakukan untuk passing data dari database MySQL ke tampilan antar muka pengunjung dengan menerapkan fitur Eloquent pada framework Laravel. Eloquent adalah object-relational mapper pada Laravel yang memungkinkan aplikasi untuk berinteraksi dengan database relational secara ringkas.

Penerapan fitur Laravel Eloquent pada implementasi fungsi sistem memberi kemudahan bagi programmer dalam penulisan kode program yang ringkas dan cepat. Hal ini dikarenakan Laravel Eloquent menyediakan berbagai fungsi-fungsi yang dapat dipanggil dengan cara sederhana.
Fungsi tersebut dibungkus ke dalam berbagai package yang menjalankan tugas tertentu sesuai kebutuhan programmer. Hal ini membantu programmer dalam melakukan penerjemahan fitur ke dalam kode program dengan penulisan sintaks yang sistematis dan terstruktur sehingga menghasilkan source code yang tertata. Berikut ini adalah tampilan antar muka aplikasi website yang sudah menerapkan framework Laravel 8.

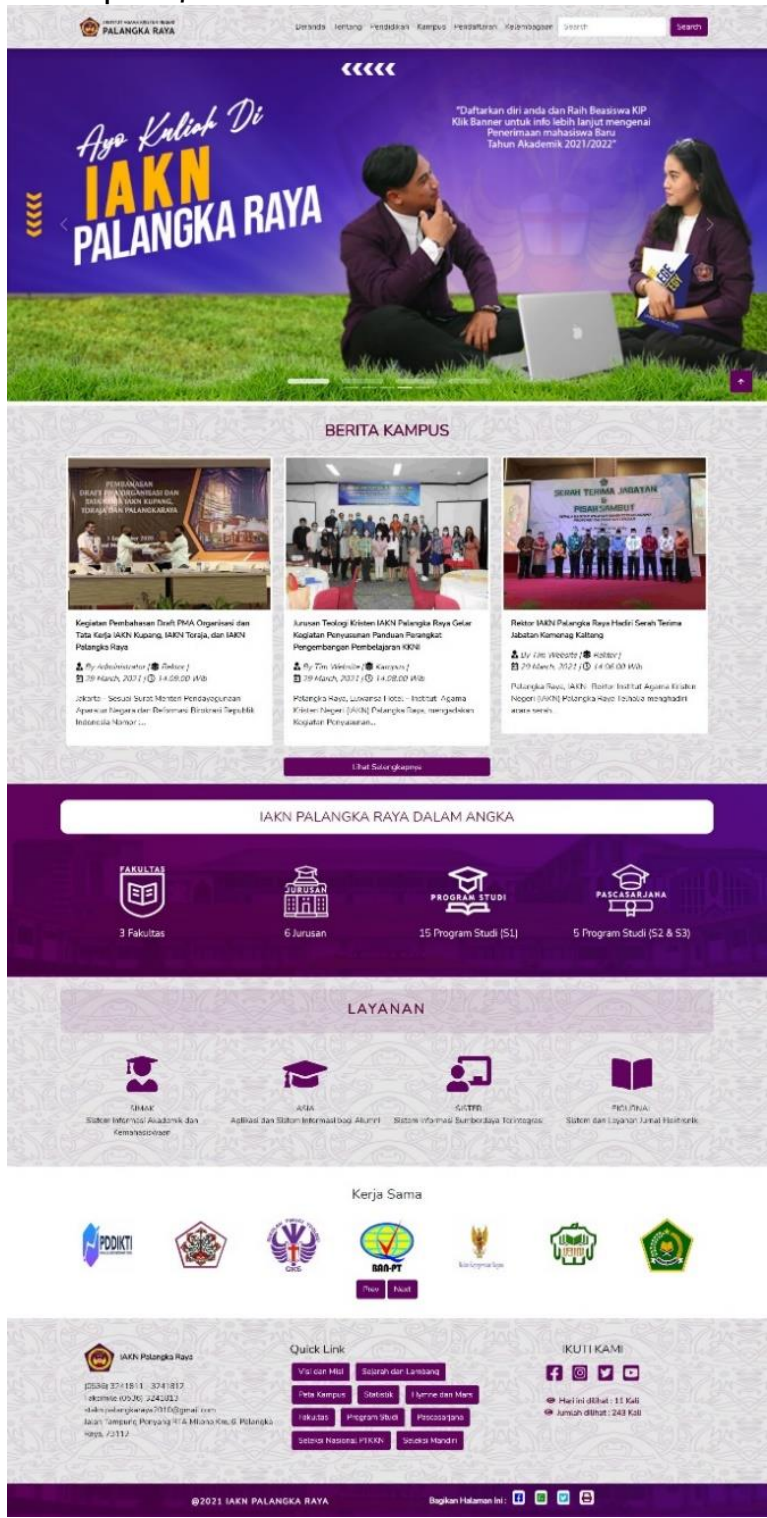

Gambar I I. Tampilan Beranda Website

Pada Gambar II, menunjukan tampilan website dengan framework Laravel, dengan memuat konten secara dinamis menyesuaikan informasi yang ada pada database. Terlihat beberapa perbedaan konten pada kolom-kolom tertentu antara desain Bootstrap 5 dan tampilan Beranda Website. Langkah selanjutnya adalah pembuatan fitur kolom halaman info website, dengan ketentuan halaman info berdasarkan keberadaan data menu navigasi yang disesuaikan dengan kebutuhan pengguna ataupun 
pengelola. Fitur kolom info menyesuaikan dengan kolom navigasi yang bersifat dinamis. Pengguna diberikan hak untuk melakukan pengolahan data navigasi yang memiliki relasi dengan halaman info. Pengolahan tersebut berupa tambah, ubah dan hapus data navigasi. Halaman info akan berubah-ubah secara otomatis berdasarkan pengolahan yang dilakukan pada menu navigasi website. Pada kolom menu navigasi disediakan fitur pencarian untuk mencari data yang ada pada website.

Pada kolom halaman carousel, foto yang diunggah berjumlah maksimal 4(empat) buah yang memiliki rasio 10:6 dan landscape orientation. Pada kolom ini foto disajikan dalam bentuk slide dengan durasi 10 detik untuk masing-masing foto slide. Kolom berita pada halaman beranda memuat 3(tiga) buah berita terbaru berdasarkan tanggal rilisnya. Kemudian pada kolom ini juga disediakan tombol untuk melihat daftar seluruh berita yang ada pada website.

Kolom 'dalam angka' menampilkan jumlah fakultas, jurusan dan program studi baik itu program sarjana atau pun program pascasarjana. Pada kolom ini terlihat perbedaan dengan desain konten kolom beranda bootstrap 5 dan Laravel 8 . Hal ini menyesuaikan kebutuhan pengguna terhadap konten yang ingin ditampilkan. Kolom layanan pada beranda website terdiri dari 4 buah menu yang berisi link url menuju website SIMAK (Sistem Informasi Akademik dan Kemahasiswaan), ASIA (Aplikasi Sistem Informasi Alumni), SISTER (Sistem Informasi Sumberdaya Terintegrasi) dan Ejournal (Open Journal System di IAKN Palangka Raya). Pada kolom kerja sama memuat logo - logo terkait dengan IAKN Palangka Raya. Pada kolom footer website memuat telepon, alamat dan email IAKN Palangka Raya. Selain itu, kolom footer juga memuat daftar quick link yang ada pada website IAKN Palangka Raya, link url menuju media sosial facebook, instagram, youtube, twitter dan jumlah pengunjung.

Berikut ini adalah tampilan halaman hasil pencarian berdasarkan fitur pencarian di menu navigasi.

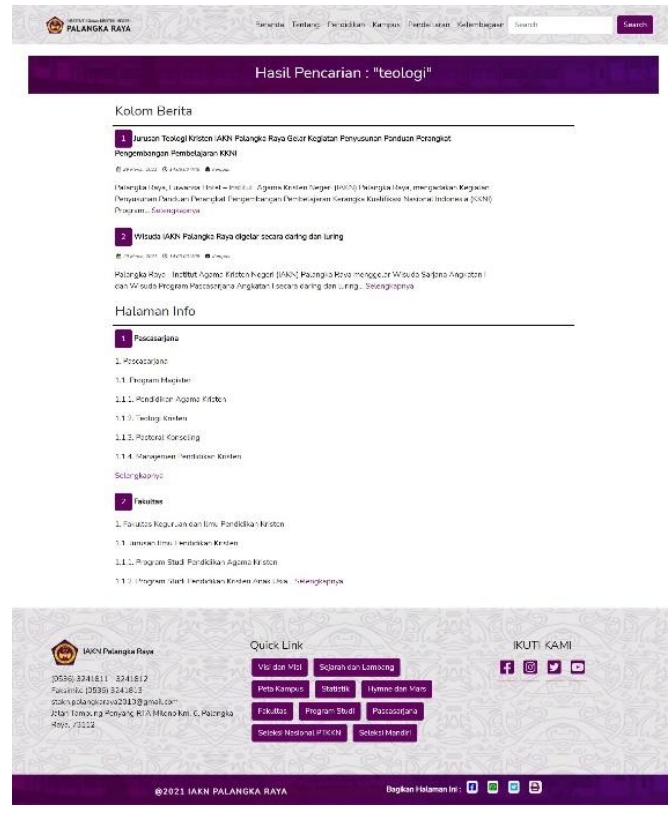

Gambar 12. Tampilan Hasil Pencarian

Hasil pencarian terbagi menjadi 2(dua) jenis yaitu hasil pencarian berita dan hasil pencarian halaman info. Hal ini memberi kemudahan untuk pengguna dalam membedakan jenis halaman dan jenis konten yang ingin dicari atau dituju. Fitur pencarian ini menggunakan Laravel Scout yaitu sebuah metode full-text search dengan Algolia Driver yang memanfaatkan himpunan data berkonsep indexed data. Penerapan Laravel Scout dalam fitur pencarian akan meningkatkan akurasi hasil dan performa proses pencarian data.

Berikut ini adalah tampilan halaman daftar berita. 


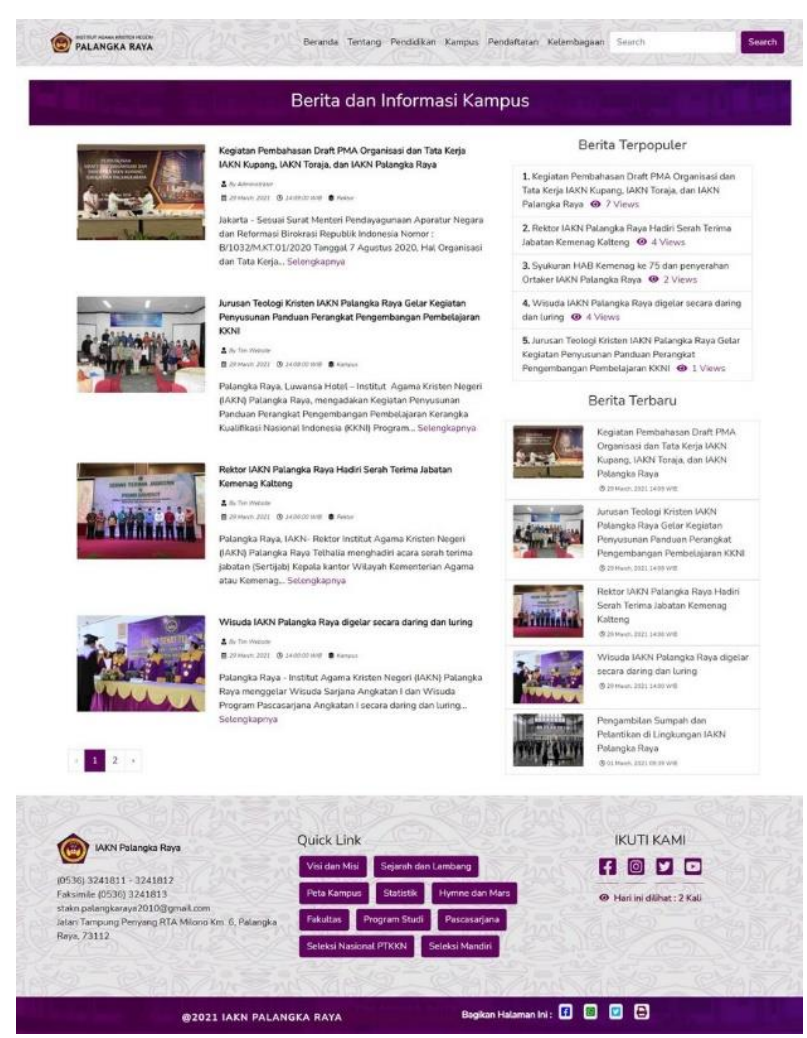

Gambar 13. Tampilan Halaman Daftar Berita

Pada halaman daftar berita memuat berita terbaru sebanyak 4 (empat) buah berita per halaman, 5 (lima) buah berita terpopuler berdasarkan jumlah viewer dan 5 (lima) buah berita terbaru berdasarkan tanggal rilis berita. Berita yang ditampilkan pada halaman ini disajikan secara ringkas yang memuat judul, author, waktu rilis, dan kategori berita. Berita yang ditampilkan pada halaman ini bersifat dinamis, menyesuaikan konten yang dikelola oleh pengelola website. Untuk memperoleh berita lengkap, pengguna akan diarahkan menuju halaman selengkapnya dengan cara memilih berita yang diinginkan.

Berikut ini adalah tampilan halaman berita secara lengkap pada saat pengguna melihat berita selengkapnya.

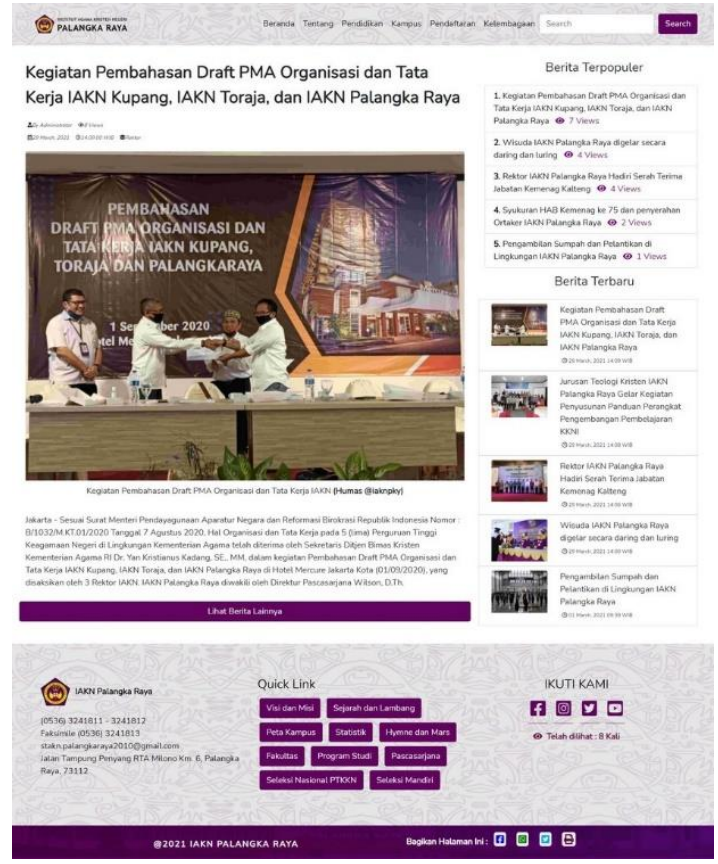

Gambar 14. Tampilan Halaman Berita Lengkap Pada tahap selanjutnya, website mock-up masuk pada tahapan pengujian terhadap fitur dan fungsinya untuk memastikan website dapat digunakan dengan baik. Tahapan pengujian yang pertama adalah uji fitur mobile responsive website. Pengujian ini dilakukan untuk mengetahui fleksibilitas tampilan atau kemampuan website untuk melakukan penyesuaian antar muka secara otomatis sehingga konten tetap bisa disajikan dengan baik di berbagai ukuran layar perangkat. Pada tahapan ini, dilakukan uji coba akses website menggunakan perangkat simulasi yang berbeda-beda, yaitu Laptop, Smartphone Google Pixel 2 dan Iphone X. Pengujian ini dilakukan dengan memanfaatkan fitur simulasi yang ada pada peramban Google Chrome. Selain itu, pengujian juga dilakukan dengan cara mengakses langsung webserver xampp menggunakan smartphone yang terhubung secara lokal pada jaringan wifi. Berikut ini hasil pengujian mobile responsive website.

Tabel 3. Hasil Ujicoba Mobile Responsive

\begin{tabular}{|l|l|l|}
\hline No & Halaman & Hasil \\
\hline $\mathbf{I}$ & Beranda & Berhasil \\
\hline 2 & Hasil Pencarian & Berhasil \\
\hline 3 & Halaman Info & Berhasil \\
\hline 4 & Daftar Berita & Berhasil \\
\hline 5 & Berita Selengkapnya & Berhasil \\
\hline
\end{tabular}

Berdasarkan hasil pengujian, mobile responsive yang ada pada website mampu berfungsi dengan baik. Website mampu melakukan perubahan posisi konten secara dinamis menyesuaikan ukuran layar perangkat. Berikut ini 
adalah tampilan halaman beranda saat uji coba mobile responsive website.

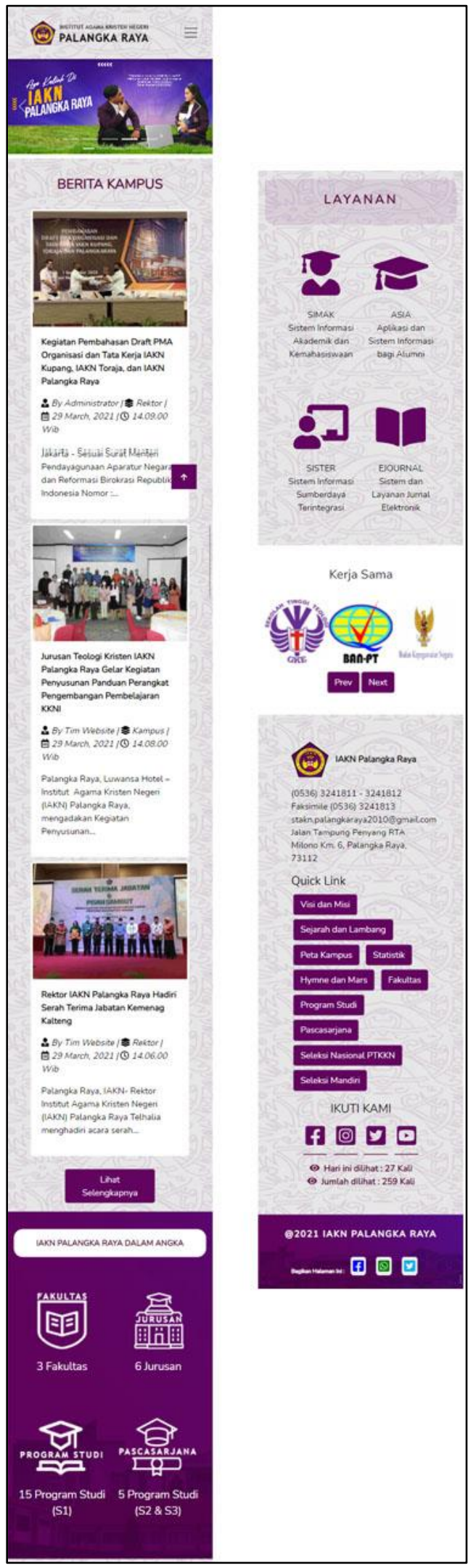

Gambar 15. Tampilan Mobile Responsive Website Tahapan selanjutnya adalah ujicoba terhadap fungsi website untuk menjamin informasi yang disajikan sesuai dengan informasi yang ada pada database. Berikut ini adalah hasil ujicoba fitur / fungsi yang ada pada website.

Tabel 4. Hasil Ujicoba Fitur / Fungsi Website

\begin{tabular}{|c|c|c|c|}
\hline No & Fitur / Fungsi & Halaman & Ket. \\
\hline $\mathrm{I}$ & Menu Navigasi & Beranda & $\ddot{u}$ \\
\hline 2 & Pencarian & Beranda & $\ddot{\mathrm{u}}$ \\
\hline 3 & Carousel Slide & Beranda & $\ddot{u}$ \\
\hline 4 & Berita Beranda & Beranda & $\ddot{\mathrm{u}}$ \\
\hline 5 & IAKN Dalam Angka & Beranda & $\ddot{\mathrm{u}}$ \\
\hline 6 & Layanan & Beranda & $\ddot{\mathrm{u}}$ \\
\hline 7 & Quick Link Footer & Beranda & $\ddot{\mathrm{u}}$ \\
\hline 8 & Link Media Sosial Footer & Beranda & $\ddot{\mathrm{u}}$ \\
\hline 9 & Viewer Counter & Beranda & $\ddot{\mathrm{u}}$ \\
\hline 10 & Menu Navigasi & Hasil Pencarian & $\ddot{\mathrm{u}}$ \\
\hline 11 & Pencarian & Hasil Pencarian & $\ddot{\mathrm{u}}$ \\
\hline 12 & Quick Link Footer & Hasil Pencarian & $\ddot{\mathrm{u}}$ \\
\hline 13 & Link Media Sosial Footer & Hasil Pencarian & $\ddot{\mathrm{u}}$ \\
\hline 14 & Menu Navigasi & Halaman Info & $\ddot{\mathrm{u}}$ \\
\hline 15 & Pencarian & Halaman Info & $\ddot{\mathrm{u}}$ \\
\hline 16 & Konten Info & Halaman Info & $\ddot{\mathrm{u}}$ \\
\hline 17 & Quick Link Footer & Halaman Info & $\ddot{\mathrm{u}}$ \\
\hline 18 & Link Media Sosial Footer & Halaman Info & $\ddot{\mathrm{u}}$ \\
\hline 19 & Eloquent Viewable & Halaman Info & $\ddot{\mathrm{u}}$ \\
\hline 20 & Menu Navigasi & Daftar Berita & $\ddot{\mathrm{u}}$ \\
\hline 21 & Pencarian & Daftar Berita & $\ddot{\mathrm{u}}$ \\
\hline 22 & Fitur Halaman & Daftar Berita & $\ddot{\mathrm{u}}$ \\
\hline 23 & Berita Terpopuler & Daftar Berita & $\ddot{\mathrm{u}}$ \\
\hline 24 & Berita Terbaru & Daftar Berita & $\ddot{\mathrm{u}}$ \\
\hline 25 & Quick Link Footer & Daftar Berita & $\ddot{\mathrm{u}}$ \\
\hline 26 & Link Media Sosial Footer & Daftar Berita & $\ddot{\mathrm{u}}$ \\
\hline 27 & Viewer Counter & Daftar Berita & $\ddot{u}$ \\
\hline 28 & Menu Navigasi & Berita Lengkap & $\ddot{\mathrm{u}}$ \\
\hline 29 & Pencarian & Berita Lengkap & $\ddot{\mathrm{u}}$ \\
\hline 30 & Isi Berita & Berita Lengkap & $\ddot{\mathrm{u}}$ \\
\hline 31 & Quick Link Footer & Berita Lengkap & $\ddot{\mathrm{u}}$ \\
\hline 32 & Link Media Sosial Footer & Berita Lengkap & $\ddot{\mathrm{u}}$ \\
\hline
\end{tabular}




$$
\begin{array}{c|l}
\text { Jurnal Sains Komputer dan Teknologi Informasi } & \text { Page } \\
\text { e-issn: 2655 7460. Volume 3 No.2, Mei 2021 } & 87-96
\end{array}
$$

\begin{tabular}{|l|l|l|l|}
33 & Eloquent Viewable & Berita Lengkap & ü \\
\hline
\end{tabular}
Ujicoba tersebut dilakukan oleh web admin, selaku pengguna / pengelola website. Berdasarkan hasil pengujian, website mampu berfungsi dengan baik sesuai rancangan. Namun demikian, tetap ada saran dan masukan dari pengguna ataupun programmer untuk pengembangan sistem dalam jangka panjang. Pada penelitian ini, diketahui bahwa metode pengembangan perangkat lunak prototype mampu menghasilkan sistem dengan fungsi tertentu namun dalam waktu yang singkat. Sehingga perlu dilakukan pengembangan lanjutan untuk penggunaan sistem dalam jangka panjang.

\section{PENUTUP}

\section{Kesimpulan}

Berdasarkan hasil penelitian mengenai penerapan framework Laravel pada website, diketahui bahwa fungsi dan fitur yang ada pada website berjalan dengan baik sebagaimana mestinya sehingga bisa digunakan sebagai website institusi bagi IAKN Palangka Raya. Seluruh informasi mengenai IAKN Palangka Raya dapat disajikan secara menarik dan aktual melalui website. Penggunaan website diharapkan bisa meningkatkan kualitas ketersediaan dan layanan informasi terkait IAKN Palangka Raya bagi masyarakat ataupun civitas akademika secara mudah, tepat dan cepat.

\section{Saran}

Website ini masih berbentuk prototype sehingga memerlukan pengembangan lanjutan agar dapat berfungsi lebih baik. Pengembangan tersebut terkait penambahan fitur search engine optimization (SEO) termasuk pengelolaan metadata dan integrasi google analytic, fitur image optimization, fitur content management system pada sisi backend, fitur page sharing, fitur galeri album, dan repositori berkas.

\section{DAFTAR ISI}

\section{Jurnal/Prosiding/Disertasi/Tesis/Skripsi}

Ariawan, M. D., Triayudi, A., \& Sholihati, I. D. (2020). Perancangan User Interface Design dan User Experience Mobile Responsive Pada Website Perusahaan. JURNAL MEDIA INFORMATIKA BUDIDARMA, 4(I), I6I-I66.
Aziz, A., Nahak, I. A., Rismayanti, I., \& Ramadian, A. A. (2020). Sistem Status Kelaikudaraan Pesawat Udara Berbasis Website Menggunakan Framework Codelgniter dan PostgreSQL dengan Metode Prototype. Jurnal Informatika Universitas Pamulang, 5(4), 5I5-520.

Megawaty, D. A. (2020). SISTEM MONITORING KEGIATAN AKADEMIK SISWA MENGGUNAKAN WEBSITE. Jurnal Tekno Kompak, I4(2), 98-I0I.

Sari, D. P., \& Wijanarko, R. (2020). Implementasi Framework Laravel pada Sistem Informasi Penyewaan Kamera (Studi Kasus di Rumah Kamera Semarang). Jurnal Informatika dan Rekayasa Perangkat Lunak, 2(I), 32-36.

Spurlock, J. (20I3). Bootstrap: Responsive Web Development. O'Reilly Media, Inc.

Yoko, P., Adwiya, R., \& Nugraha, W. (2019). Penerapan Metode Prototype dalam Perancangan Aplikasi SIPINJAM Berbasis Website pada Credit Union Canaga Antutn. Jurnal Ilmiah Merpati (Menara Penelitian Akademika Teknologi Informasi), 2 I2223.

\section{Buku}

Khosrow-Pour, D. B. (2005). Encyclopedia of information science and technology. IGI Global.

\author{
Lain-lain \\ Mark Otto. (202I). Bootsrap 5 Documentation. \\ https:/getbootstrap.com/docs/5.0/getting- \\ started/introduction/ (Diakses tanggal 24 Maret \\ 202I). \\ Taylor Otwell. (202I). Laravel Documentation. \\ https://laravel.com/docs/8.x (Diakses tanggal 2 \\ April 2021).
}

